\title{
ABU BATUBARA DAN PEMANFAATANNYA: TINJAUAN TEKNIS KARAKTERISTIK SECARA KIMIA DAN TOKSIKOLOGINYA
}

\section{Coal Ash and Its Utilization: A Technical Review on Its Chemically Characteristics and Toxicology}

\author{
RETNO DAMAYANTI \\ Puslitbang Teknologi Mineral dan Batubara \\ Jalan Jenderal Sudirman 623 Bandung 40211 \\ Telp. (022) 6030483, Fax. (022) 6003373 \\ e-mail: retno.damayanti@esdm.go.id
}

\begin{abstract}
ABSTRAK
Pemenuhan kebutuhan energi di Indonesia masih didominasi oleh bahan bakar fosil seperti minyak, gas ataupun batubara. Sampai dengan 2050 diperkirakan kontribusi batubara sebagai sumber energi masih mencapai $31 \%$. Pembangunan PLTU 35 GW merupakan salah satu solusi pemenuhan kebutuhan energi. Konsekuensinya abu batubara akan banyak terbentuk dan ditimbun apabila tidak bisa dimanfaatkan. Berdasarkan kondisi ini pemanfaatan abu batubara secara masif perlu diupayakan dengan tetap mempertimbangkan statusnya sebagai limbah B3. Penelitian terkait pemanfaatan abu batubara berikut penunjangnya sudah dilakukan di Puslitbang Teknologi Mineral dan Batubara sejak tahun 2000 namun penelitian ini masih dilakukan pada skala laboratorium karena percobaan di lapangan perlu waktu dan perizinan yang cukup lama. Berdasarkan karakterisasi percontoh yang diambil dari PLTU di Jawa Barat, Jawa Timur, Sumatera dan Kalimantan diketahui bahwa abu batubara ada yang bersifat asam dan basa serta memiliki kandungan logam berat seperti $\mathrm{Fe}, \mathrm{Mn}, \mathrm{Pb}, \mathrm{Cu}, \mathrm{Zn}, \mathrm{Ni}, \mathrm{Cr}$, dan $\mathrm{Co}$. Beberapa pengujian untuk melihat sifat keterlindian logam-logam berat dan sifat toksik secara kimia dan biologi menunjukkan bahwa percontoh abu batubara dapat dikategorikan sebagai bukan limbah B3 (kandungan logam-logam berat tersebut dalam lindiannya lebih kecil dari yang ditetapkan) dan bersifat hampir tidak toksik (dengan nilai $10.000<$ LC50 < $100.000 \mathrm{ppm}$ ) dan relatif tidak berbahaya (LD $50>15.000 \mathrm{ppm}$ ). Pengujian laboratorium menunjukkan tidak terjadi pelindian logam berat yang signifikan, terbukti bahwa logam-logam berat dalam abu batubara pada pengujian spesiasi terdistribusi pada fraksi oksida dan residu yang secara kimia menbuat logam-logam tersebut tidak mudah terlindi. Implementasi di lapangan dengan perencanaan pemantauan yang baik dan benar, kolaborasi dengan KLHK perlu dilakukan agar pemanfaatan limbah yang aman untuk lingkungan dapat direalisasikan.
\end{abstract}

Kata kunci: Abu batubara, logam berat, karakteristik abu batubara, toksisitas, pelindian.

\begin{abstract}
Energy needs compliance in Indonesia is dominated by fossil fuels such as oil, gas or coal. Up to 2050 estimated coal contribution as a source of energy reaches about $31 \%$. The construction of PLTU 35 GW is one of the solutions to meet the energy needs. Consequently coal ash will be much formed and dumped if it can not be utilized. Under this condition, the massive utilization of coal ash should be sought by considering its status as B3 waste. The research related to the utilization of coal ash along with its support has been done in R\&D Centre for Mineral and Coal Technology since 2000 but this research is still at laboratory scale because field experiments consume time and require an approval. Based on the characterization of samples taken from PLTU in West Java, East Java, Sumatera and Kalimantan, it concludes that coal ash is either acidic or alkaline
\end{abstract}


and contains heavy metals such as $\mathrm{Fe}, \mathrm{Mn}, \mathrm{Pb}, \mathrm{Cu}, \mathrm{Zn}, \mathrm{Ni}, \mathrm{Cr}$, and $\mathrm{Co}$. The test for heavy metals leaching and chemicals and biological toxicological properties indicate that samples can be categorized as non-B3 material (the heavy metal content in the leachate is smaller than specified) and is almost non-toxic (with value $10.000<L C 50<100.000 \mathrm{ppm}$ ) and relatively harmless (LD $50>15.000 \mathrm{ppm}$ ). Laboratory tests also show no significant heavy metals leaching due to heavy metals in coal ash are distributed on the oxide and the residues fractions in the speciation test which make them not leachable easily. Implementation in the field with good and proper monitoring planning, and collaboration with KLHK need to be done so that the environmentally safe utilization of waste can be realized.

Keywords: Coal ash, heavy metals, coal ash characteristics, toxicity, leaching.

\section{PENDAHULUAN}

Saat ini, kebutuhan energi di Indonesia diperkirakan sebesar 1.050,3 juta barel setara minyak dan 50\% nya masih berasal dari bahan bakar impor (Permana $d k k ., 2010$ ). Dengan adanya rencana pembangunan beberapa Pembangkit Listrik Tenaga Uap (PLTU) baru dengan kapasitas total 35.000 MW atau $35 \mathrm{GW}$, baik di dalam maupun luar Jawa, maka permasalahan lingkungan yang dianggap cukup penting dari kegiatan industri penghasil energi berbahan bakar batubara tersebut adalah masalah abu batubara. Limbah padat yang dihasilkan tersebut diperkirakan akan bertambah secara signifikan dan semakin bertumpuk bila tidak dapat dimanfaatkan secara masif.

Abu batubara dari proses pembangkit listrik dibedakan dalam beberapa macam yakni abu terbang (fly ash), abu dasar (bottom ash) dan boiler slag. Pemanfaatan abu batubara untuk berbagai keperluan sangat tergantung dari sifatsifat abunya, yang ditentukan dari kandungan kimia di dalamnya (Suprapto dan Damayanti, 1988). Sifat abu batubara sangat ditentukan dari karakteristik batubaranya. Pada pembakaran batubara lignit dan batubara subbituminus akan dihasilkan produk samping abu yang berbeda karakteristiknya. Oleh karena abu batubara diklasifikasikan sebagai limbah B3 kategori 2 yang berasal dari sumber khusus (Presiden Republik Indonesia, 2014), maka beberapa parameter pengujian karakterisasi abu diperlukan untuk pengelolaannya, dan salah satunya adalah dengan pengujian toksisitas terhadap abu batubara.

Pemanfaatan abu limbah pembakaran batubara dari PLTU ini diharapkan mampu mengurangi penumpukan abu batubara secara signifikan melalui pemanfaatannya sebagai bahan untuk pengolahan limbah air asam tambang dari Industri Penambangan Batubara.

Penelitian abu batubara yang berasal dari PLTU berbahan bakar batubara telah banyak dilakukan di manca negara ataupun di Indonesia. Beberapa negara seperti Amerika, Jepang dan Belanda, abu terbang dikatagorikan sebagai limbah yang tidak berbahaya, bahkan ada yang menganggap abu terbang sebagai sumber mineral dan komoditi perdagangan yang sangat berharga (PLN, 1997). Berbagai institusi riset dan perguruan tinggi di Indonesia telah melakukan penelitian terkait dengan pemanfaatannya secara masif guna mengurangi timbunan yang ada.

Di Indonesia abu batubara dikatagorikan sebagai limbah berbahaya, salah satu penyebabnya karena adanya unsur-unsur logam berbahaya seperti $\mathrm{Mn}, \mathrm{Pb}, \mathrm{Cu}, \mathrm{Zn}, \mathrm{Cd}$, $\mathrm{Cr}, \mathrm{Co}, \mathrm{Hg}$, Se, V dan As. Puslitbang tekMIRA sebagai salah satu instirusi riset di bawah Kementerian Energi dan Sumberdaya Mineral (KESDM) juga telah melakukan penelitian abu batubara terutama dikaitkan dengan permasalahan pertambangan. Pengujian terkait prediksi terjadinya pelindian logam-logam berat yang dikandungnya harus diantisipasi.

Penelitian-penelitian tersebut telah dikembangkan di Puslitbang tekMIRA sejak tahun 1988, terutama untuk memenuhi spesifikasi pada berbagai macam pemanfaatan di dunia pertambangan.

\section{Produksi Abu Batubara}

Dalam menggerakkan roda pembangunan dan perekonomian, tidak dapat dipungkiri bahwa energi menjadi ujung tombak keberhasilan pencapaiannya. Berdasarkan fakta tersebut, batubara sebagai salah satu komoditas energi 
seharusnya tidak hanya diperlakukan sebagai penambah devisa.

Pada saat ini produksi pertambangan batubara mengalami perkembangan yang sangat pesat. Dalam kurun waktu 4 tahun terakhir, sumberdaya batubara diketahui mengalami sedikit peningkatan, namun cadangan batubara mengalami penurunan akibat peningkatan produksi batubara, baik untuk konsumsi domestik maupun untuk komoditas ekspor. Dengan model produksi seperti saat ini, cadangan batubara diperkirakan akan habis dalam waktu 70 tahun bila tidak diimbangi dengan penemuan cadangan baru (Fitriana $d k k ., 2017$ ).

Target produksi batubara Indonesia berdasarkan Rencana Pembangunan Jangka Menengah (RPJMN) 2015 - 2019 (Tabel 1.) menunjukkan kecenderungan penurunan produksi. Kebutuhan domestik dalam RPJMN tersebut diharapkan mengalami peningkatan seiring dengan rencana realisasi pembangunan PLTU dan ekspor mulai dikurangi. Hal ini berarti menargetkan peningkatan konsumsi batubara domestik hingga $60 \%$ dari produksi nasional atau mencapai 240 juta ton pada 2019 (BAPPENAS, 2016). Pemanfaatan dalam negeri yang utama adalah sebagai bahan bakar di PLTU, yang berada pada kisaran 45,20 75,4 juta ton pada 2011 - 2016. Berdasarkan laporan kinerja Direktorat Jenderal Mineral dan Batubara (2018), diketahui bahwa realisasi produksi batubara pada 2015 - 2017 sesudah pelaksanaan rekonsiliasi dengan Pemerintah Daerah (Pemda) mengalami peningkatan dari target awal pada 2015 dan 2016 (Tabel 2).

\section{Konsumsi Batubara dan Produksi Energi}

Pada saat ini ketidakseimbangan tingkat pertumbuhan pembangunan energi dan kebutuhan energi, khususnya listrik, memicu perlunya percepatan dalam pembangunan sektor ketenagalistrikan. Menurut informasi dari Direktorat Jenderal Ketenagalistrikan (DJK), pada 2015 total kapasitas terpasang nasional yang dibangun oleh PLN dan swasta mencapai $55 \mathrm{GW}$, terdiri dari PLTU PLN sebesar 38 GW dan PLTU non PLN sebesar 17 GW (Direktorat Jenderal Ketenagalistrikan, 2016).

Rencana penambahan target listrik sebesar 35 GW bukanlah target yang ringan. Per tahun paling tidak harus ada penambahan kurang lebih 7 GW. Kondisi penambahan ini direncanakan dengan mempertimbangkan pertumbuhan ekonomi dalam kisaran $6-7 \%$ per tahun.

Saat ini, kebutuhan energi di Indonesia diperkirakan sebesar 1.050,3 juta barel setara minyak dan $50 \%$ nya masih berasal dari bahan bakar impor. Dengan adanya rencana pembangunan beberapa PLTU baru dengan kapasitas total $35.000 \mathrm{MW}$ atau $35 \mathrm{GW}$, baik di dalam maupun luar Jawa, maka akan ada peningkatan kebutuhan batubara di dalam negeri.

Konsumsi batubara domestik periode Januari - September 2015 mengalami peningkatan sebesar $9.83 \%$, dari 61 juta ton menjadi 67 juta ton karena adanya peningkatan konsumsi domestik yang didorong oleh penambahan jumlah PLTU yang beroperasi (Office of Chief Economist, 2016). Menurut PT. PLN (2018), perkiraan kebutuhan batubara untuk keperluan bahan bakar pembangkit tenaga listrik dalam negeri mencapai 97 juta ton (2018) - 162 juta ton (2027). Kondisi ini menunjukkan bahwa ke depan bauran energi masih didominasi oleh batubara sebagai sumber energi untuk pembangkitan tenaga listrik (Gambar 1).

Tabel 1. Target produksi batubara nasional pada RPJMN 2015 - 2019 (DJMB, 2018 dan Bappenas, 2016)

\begin{tabular}{ccccccc}
\hline No. & Target (Juta ton) & 2015 & 2016 & 2017 & 2018 & 2019 \\
\hline 1 & Produksi & 425 & 419 & 413 & 406 & 400 \\
2 & DMO & 102 & 111 & 121 & 131 & 240 \\
3 & Ekspor & 323 & 306 & 292 & 276 & 160 \\
\hline
\end{tabular}


Tabel 2. Realisasi produksi batubara nasional (DJMB, 2018)

\begin{tabular}{cc}
\hline Tahun & Realisasi Produksi Batubara (juta ton) \\
\hline 2015 & 461 \\
2016 & 419 \\
2017 & 461 \\
\hline
\end{tabular}

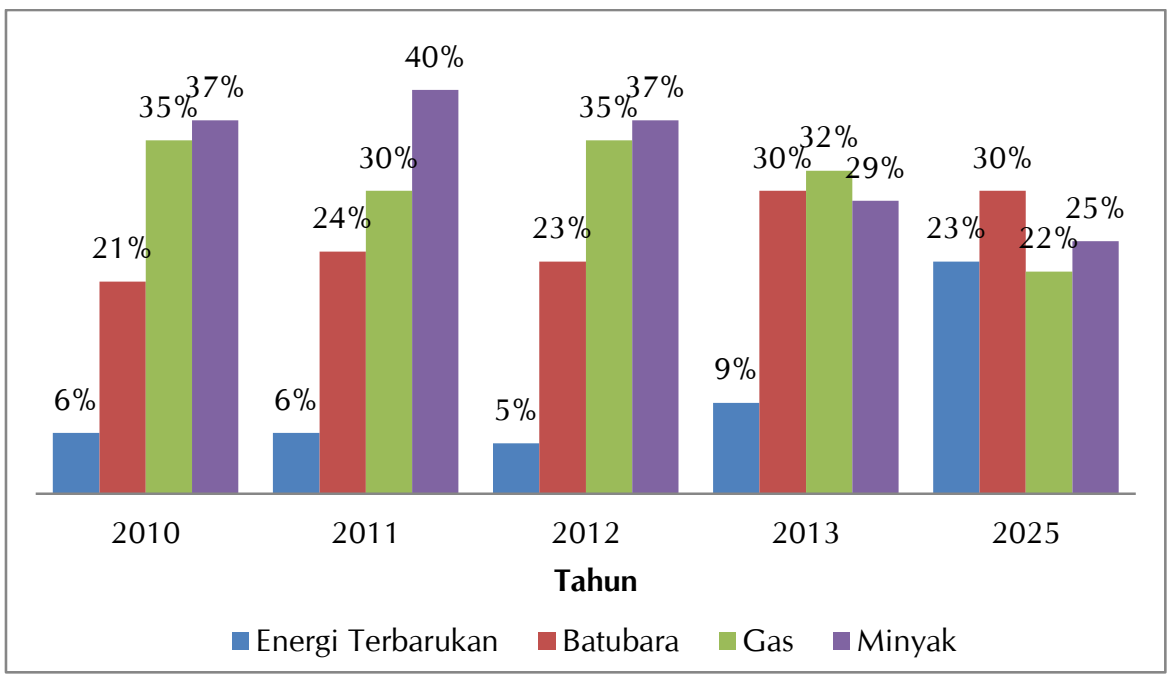

Gambar 1. Bauran energi untuk pembangkitan tenaga listrik, skenario optimistis (Hikam, 2014)

\section{Produksi Abu Batubara}

Di seluruh dunia, produksi abu batubara (fly ash dan bottom ash atau disingkat FABA) mencapai kurang lebih 780 juta ton pada 2010. Produksi abu batubara dapat dilihat pada Gambar 2. Abu batubara dalam jumlah besar disimpan dalam bentuk timbunan atau endapan, yang kontaminasinya diperkirakan menimbulkan ancaman serius terhadap lingkungan sebagai sumber utama pencemaran anorganik. Perilaku banyak polutan logam dan pelepasan logam seperti itu selama penyimpanan dapat memiliki efek merusak terhadap lingkungan dan kesehatan manusia. Logam yang ada dalam abu berasal dari komposisi batubara yang digunakan dalam pembakaran, kondisi pembakaran, efisiensi penyisihan alat kontrol polusi udara dan metode pembuangan fly ash. Kurang lebih 415 juta ton atau 53\% dari total produksi FABA dimanfaatkan secara efektif dan ini sangat bervariasi di tiap negara.

Di Indonesia batubara masih akan tetap menjadi bahan bakar utama untuk pembangkit energi, sehingga sejumlah besar produk pembakaran batubara (abu batubara) pasti akan dihasilkan. Pada rencana pembangunan listrik $35 \mathrm{GW}$, diperkirakan abu batubara akan bertambah jumlahnya. Kontribusi peningkatan jumlah abu ini akan terjadi sangat signifikan. Berdasarkan kondisi tersebut maka perlu usaha penyerapan dan pemanfaatan masif yang sebanding demi menjaga kondisi lingkungan.

Di Indonesia produksi limbah abu terbang dan abu dasar dari PLTU diperkirakan mencapai 2 juta ton pada tahun 2006, dan meningkat menjadi hampir 3,3 juta ton pada tahun 2009. Khusus untuk PLTU Suralaya, sejak tahun 2000 hingga 2006 diperkirakan ada akumulasi jumlah abu sebanyak 219.000 ton per tahun (PLN, 1997). Produksi abu terbang dari pembangkit listrik di Indonesia ini terus meningkat, pada 2000 jumlahnya mencapai 1,66 miliar ton dan mencapai 2 miliar ton pada 2006. Menurut Thahir (2017), PLTU Suralaya sebagai salah satu anak perusahaan dari PLN dan Independent Power Producer (IPP), menghasilkan limbah batubara sebesar 2,7 juta ton/tahun dan bisa terus bertambah hingga 11,2 juta ton/tahun pada 2027. 


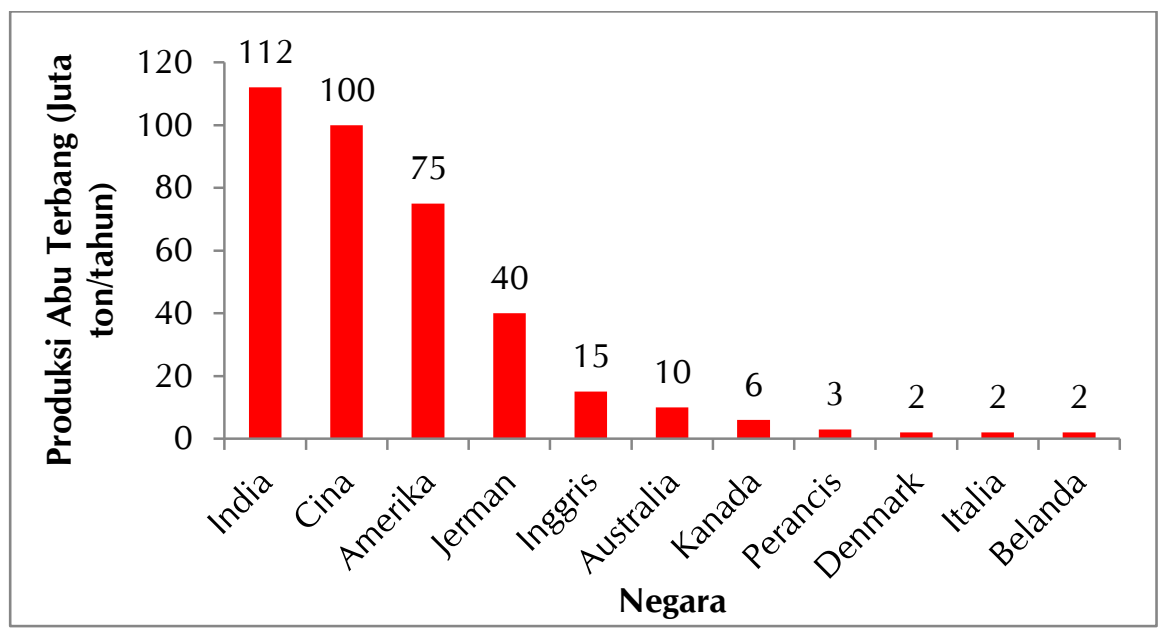

Gambar 2. Produksi abu batubara di dunia (Dwivedi dan Jain, 2014)

PLTU sebagai penyumbang terbesar produksi FABA akan menjadi penyumbang pencemaran pula bagi lingkungan jika tidak menangani masalah FABA ini dengan baik. Salah satu kemungkinan penanganannya adalah dengan memanfaatkan FABA ini secara masif untuk bahan baku konstruksi, semen, pembuatan refraktori, road base. Pemanfaatan lain seperti bahan pembenah lahan, material penetral, absorber dapat pula dipakai namun tidak semasif pada pemanfaatan sebagai material konstruksi.

\section{Abu Batubara dan Masalah Lingkungan}

Seperti di Indonesia, batubara dimanfaatkan sebagai sumber energi utama di Cina, dan FABA sebagai material yang tersisa dari pembakaran batubara, juga dianggap sebagai limbah dan harus disimpan atau dibuang. Persamaan lain, Cina juga menghasilkan abu terbang dalam jumlah besar dan mendapat perhatian publik yang cukup besar pula.

Salah satu contoh lokasi pembuangan FABA di Indonesia adalah di PLTU Paiton Jawa Timur, mempunyai luas keseluruhan kira-kira $29 \mathrm{Ha}$ yang sudah diratakan dan dipadatkan untuk pengelolaan FABA. Penampungan ini terdiri dari satu laguna penampung $F A$, satu laguna penampung $B A$ dan satu laguna penampung air limpasan yang dirancang dengan sistem tertutup yang dilengkapi dengan sistem penyekat dengan pengaturan permeabilitas sesuai aturan yang ditetapkan (Sprint Consultant, 2015).
FABA dianggap sebagai sumber limbah padat tunggal industri terbesar pada saat ini. Zat-zat yang bersifat racun dalam FABA diperkirakan tidak hanya mencemari tanah, udara dan air setempat, tetapi juga akan menyebabkan kerusakan pada kesehatan manusia melalui rantai makanan.

Ada kecurigaan bahwa upaya pemanfaatan yang berlebihan pada saat ini terjadi akibat tekanan dari kelompok perlindungan lingkungan, baik terkait masalah isu pemanasan global ataupun pencemaran bahanbahan beracun dan berbahaya yang terkandung di dalamnya. Di beberapa negara seperti India dan Amerika Serikat hasil dan data pada studi yang dilakukan untuk pengurangan $\mathrm{CO}_{2}$ dengan menggunakan batubara untuk proses ko-produksi energi dan semen, dan juga studi sebelumnya pada konversi abu terbang ke dalam semen, membuktikan bahwa adalah mungkin untuk menghasilkan suspensi abu terbang dalam tungku pembakaran yang menggunakan bahan bakar batubara. Pola industri tersebut memungkinkan pemanfaatan abu terbang menjadi lebih sempurna (masif), dapat mengurangi emisi gas rumah kaca dan melestarikan sumber daya. Kondisi tersebut juga akan lebih efisien dalam penghematan biaya konstruksi dan penghapusan polusi terhadap udara, air dan tanah (Joshi, 2010).

Menurut Lokeshappa dan Dikshit (2012), abu batubara mengandung logam beracun dalam konsentrasi yang jauh lebih tinggi apabila dilepaskan ke lingkungan oleh pembangkit listrik berbahan bakar batubara di Amerika 
Serikat. Pembuangan abu batubara di kolam penampungan terbuka dan tidak dilindungi pelapis, akan menyebabkan dampak lingkungan yang buruk dan serius. Hal ini disebabkan oleh konsentrasi logamnya yang tinggi dan kemungkinan pelindiannya ke tanah dan air tanah. Kajian terkait transformasi logam (arsenik, dan kromium) yang berasal dari tiga macam model kolam penampungan abu yang mengandung FABA dari tiga PLTU yang berbeda menunjukkan bahwa seiring peningkatan usia kolam abu, maka konsentrasi semua logam dalam FABA menurun. Namun demikian, konsentrasi logam dalam kolom air bebas menjadi lebih dari $150 \mu \mathrm{g} / \mathrm{L}$ (ppb). Logam-logam berat yang diperkirakan ada dalam FABA asal AS ini adalah As, $\mathrm{Se}, \mathrm{Cr}, \mathrm{Zn}$, $\mathrm{Pb}$, Li dan $\mathrm{Ba}$.

Pengklasifikasian toksisitas berdasarkan kandungan logam total dalam FABA akan memberikan hasil perkiraan potensi bahaya ekotoksikologi yang secara drastis melebihi hasil pengujian berdasarkan eluatnya (Stiernström dkk., 2012).

Berkaitan dengan masalah kandungan logam dalam FABA tersebut, United State Environmental Protection Agency (US EPA) pada 2014 telah mengeluarkan aturan baru terkait pembuangan FABA. Investigasi laboratorium tentang toksisitas sering menghasilkan perkiraan toksisitas yang sifatnya konservatif. Hal ini karena banyak spesies uji standar yang digunakan lebih sensitif daripada spesies residen, sehingga hasil yang diperoleh dapat memberikan informasi yang berguna untuk pembuatan aturan. Namun demikian, beberapa kajian laboratorium tentang toksisitas FABA sudah tersedia; sebagian besar kajian yang dilaporkan dalam literatur hanya didasarkan pada investigasi lapangan. Kajian toksisitas yang dilakukan untuk Tennessee Valley Authority (TVA) Kingston ash spill di AS, memberikan hasil yang dapat membantu memberikan perspektif tambahan tentang toksisitas abu batubara. Risiko moderat ditemukan pada spesies residen dan terbatas pada lokasi dengan kandungan abu $\geq 40 \%$ (Sherrard, Carriker dan Greeley, 2015).

Polutan yang terkait dengan $\mathrm{FA}$, termasuk beberapa elemen seperti $\mathrm{Al}, \mathrm{As}, \mathrm{Cd}, \mathrm{Cr}, \mathrm{Cu}$, $\mathrm{Hg}$, Ni, Pb, dan $\mathrm{V}$, keberadaannya yang berlebihan di lingkungan dapat bersifat racun. Dalam studi lain di AS, dibahas toksikologi lingkungan terkait unsur-unsur jejak tersebut yang ada dalam abu batubara. Berdasarkan tinjauan pustaka dan analisis kimia terhadap FA batubara, maka konsentrasi unsur-unsur yang disebutkan di atas telah dapat ditentukan kemungkinan potensi kondisi toksiknya dengan menggunakan spektrometri plasma induktif (Inductively Coupled Plasma atau ICP). Perbandingan konsentrasi unsur-unsur tersebut dengan tingkat konsentrasinya di tanah, dan sumber air diketahui cukup beragam (Hecker dan Bilski, 2014).

Di India, kadar abu pada batubara bituminus dan sub-bituminus yang digunakan di pembangkit listriknya sebesar $40 \%$. Saat ini, 120-150 juta ton abu terbang dihasilkan dari pembakaran batubaranya. Abu tersebut mengandung logam beracun seperti As, Ba, $\mathrm{Hg}, \mathrm{Cr}, \mathrm{Ni}, \mathrm{V}, \mathrm{Pb}, \mathrm{Zn}$ dan Se dalam jumlah cukup signifikan yang terkonsentrasi dalam partikel abu (Dwivedi dan Jain, 2014).

\section{Pemanfaatan Abu Batubara}

Berdasarkan beberapa pertimbangan terkait sifat FABA maka pemerintah Cina khusus memberi perhatian terhadap masalah lingkungan yang dapat ditimbulkan akibat pemanfaatannya. Di samping itu pemerintah Cina juga telah menetapkan insentif terhadap pemanfaatan yang komprehensif dan juga menyiapkan langkah-langkah pencegahan polusi yang mungkin disebabkan oleh pemanfaatannya (He, Luo dan Hu, 2012).

Berkaitan dengan masalah pemanasan global, pemanfaatan FABA diperkirakan dapat pula menurunkan jejak karbon bagi pembangkit listrik. Dengan demikian diperkirakan pemanfaatan tersebut dapat meminimalkan efek negatif terhadap lingkungan. Cina menetapkan bahwa 'hingga 2010, tingkat pemanfaatan secara komprehensif limbah padat industri harus melebihi 60\%' (Zhang, 2014).

Di Cina dilakukan penelitian sistematis dan komprehensif di laboratorium terkait perubahan kimia dan mineralogi FABA yang berasal dari batubara Indonesia peringkat rendah. Penelitian dilakukan pada saat terjadi proses pembakaran dalam tungku. Percobaan juga termasuk pembentukan FABA dengan 
menggunakan siklon yang dilengkapi filter. Pengaturan proses pada kondisi suhu 1200$1400{ }^{\circ} \mathrm{C}$ tersebut dikontrol ketat.

Di Australia, pengujian karakteristik abu yang berasal dari contoh batubara Indonesia telah dilakukan termasuk yang mengalami proses pencucian. Hasilnya menunjukkan adanya perubahan yang cukup signifikan (Vuthaluru dan French, 2008). Pengujian terhadap contoh uji menunjukkan bahwa karakteristik FABA-nya cukup bervariasi. Kombinasi penggunaan batubara yang dicampur bauksit memperlihatkan kinerja terbaik berkaitan dengan penanganan masalah abu dari batubara Indonesia.

Fakta di lapangan menunjukkan bahwa kualitas FABA sangat bervariasi di lapangan. Kondisi ini tergantung pada proses pembakaran dan kualitas batubara yang dipakai. Sifat-sifat ini akan mempengaruhi sifat fisik dan mekanik dari campuran beton yang digunakan. Penelitian ini menggunakan 12 percontoh FABA dari PLTU Indonesia. Sifat fisik dan kimia bahan tersebut selanjutnya dianalisis. FABA pada percobaan ini dicampur dengan OPC (Ordinary Portland Cement) dengan proporsi FABA $20 \%$ dan OPC $80 \%$. Pengujan ini diketahui sangat terpengaruh oleh kemurnian FABA dan kandungan karbon terhadap kuat tekan (Triwulan $d k k$., 2017).

Pada dasarnya FABA dapat dimanfaatkan untuk berbagai macam aplikasi. Di Cina, ada 6 (enam) contoh pemanfaatan FABA, yakni: a) Produksi bahan bangunan seperti semen, bata, keramik dan paving;

b) Pekerjaan bahan bangunan seperti produksi beton, mortar dll.;

c) Konstruksi jalan termasuk untuk tanggul, perkerasan landasan dan trotoar;

d) Material pengurukan yang meliputi pengurukan struktur, pengurukan konstruksi, pengisian lahan kosong, lahan tambang, area penimbunan batubara dll.;

e) Aplikasi pertanian termasuk sebagai bahan pembenah tanah, produksi pupuk majemuk dan reklamasi lahan;

f) Daur ulang untuk bahan baku yang bermanfaat.

Di India, abu batubara (FA) yang merupakan produk samping industri pembangkit listrik, terbukti sesuai untuk berbagai aplikasi seperti campuran dalam semen/beton/ mortar, campuran kapur pozzolan (batu bata/blok) dll. Semen dan Beton Industri menyumbang 50\% pemanfaatan FA. Aplikasi lainnya adalah sebagai low lying area fill $(17 \%)$, roads \& embankments $(15 \%)$, dyke raising $(4 \%)$, pembuatan bata $(2 \%)$ dan yang relatif terbaru dan dianggap aman adalah dalam industri cat, pertanian (Dwivedi dan Jain, 2014).

Di negara-negara lain, FABA umumnya banyak dimanfaatkan dalam industri semen dan beton. Di negara Asia lainnya, Australia, Eropa, Amerika dan Afrika, abu batubara banyak dimanfaatkan sebagai bahan konstruksi untuk jalan, reklamasi lahan tambang, bahan pembenah tanah dll (Tabel 3).

Tabel 3. Pemanfaatan abu batubara di manca negara (Kurniawan $d k k ., 2010$ )

\begin{tabular}{|c|c|c|}
\hline No. & Pemanfaatan & Negara \\
\hline & $\begin{array}{l}\text { Jalan raya: material untuk: semen, konkret, pembetonan } \\
\text { lereng, pengisi struktur, bahan dasar jalan, agregat sintetik, } \\
\text { pengontrol salju dan es. }\end{array}$ & India, Amerika Serikat \\
\hline 2. & $\begin{array}{l}\text { Reklamasi: umum digunakan pada reklamasi bekas tambang } \\
\text { terbuka; reklamasi pada tambang terbuka yang masih aktif; } \\
\text { remediasi dan kontrol pada penurunan muka tanah. }\end{array}$ & $\begin{array}{l}\text { India, Spanyol, Amerika Serikat, } \\
\text { Australia }\end{array}$ \\
\hline & $\begin{array}{l}\text { Aplikasi pertanian: bahan pembenah tanah; pengeras } \\
\text { halaman peternakan, alas penyimpanan jerami; }\end{array}$ & $\begin{array}{l}\text { India, Afrika Selatan, Amerika Serikat, } \\
\text { Jepang }\end{array}$ \\
\hline & $\begin{array}{l}\text { Pabrik:agregat; cat, industri semen; material pengisi pada } \\
\text { indutri plastik, karet dan alloy }\end{array}$ & $\begin{array}{l}\text { Kanada, Columbia, Italia, Belanda, } \\
\text { Afrika Selatan, Amerika Serikat dan } \\
\text { Inggris }\end{array}$ \\
\hline & $\begin{array}{l}\text { Teknik sipil: batako, paving blok, media, penstabil sampah, } \\
\text { media }\end{array}$ & $\begin{array}{l}\text { Belgia, Denmark, Perancis, Jerman, } \\
\text { Yunani, Finlandia, India, Belanda, } \\
\text { Spanyol, Inggris dan Amerika Serikat }\end{array}$ \\
\hline
\end{tabular}


Pemanfaatan sebagai bahan konstruksi ini menjadi menarik karena adanya sifat-sifat pozolan di dalam FABA tersebut dan juga karena alasan lingkungan yang didasarkan pada perkiraan bahwa logam-logam berbahaya akan tertahan dengan kuat pada matriks semen dan beton. Di samping itu, abu batubara juga banyak dimanfaatkan sebagai bahan pengisi pada bahan tambang, bahan galian dan bahan bangunan.

Pada PLTU Paiton di Jawa Timur, lebih dari 98\% FA yang dihasilkan sudah dimanfaatkan oleh industri semen dan ready mix (Sprint Consultant, 2015). Partikel FA yang dipancarkan dari pembangkit listrik berbahan bakar batubara telah diketahui mengandung beberapa logam jejak beracun. Oleh karena ketersediaan abu batubara (FA) biasanya dalam jumlah besar dan konsentrasi Ca dan Mg dalam abu yang tinggi dalam banyak contoh abu batubara, maka diperkirakan FA dapat dimanfaatkan sebagai pembenah tanah yang sesuai untuk tujuan pembatasan dan untuk meningkatkan kandungan $\mathrm{Ca}$ dan $\mathrm{Mg}$ di dalam tanah. Pemanfaatan FA sebagai pembenah tanah menunjukkan perlunya mengambil tindakan pencegahan terhadap akumulasi berlebihan logam berat oleh tanaman dalam media yang dicampur dengan FA batubara. Keragaman sifat kimia di antara FA menunjukkan bahwa setiap penggunaan FA sebagai pembenah tanah harus mengikuti analisis kimia rinci karena telah ditetapkan bahwa lindi dari tempat-tempat dengan konsentrasi FA tinggi dapat mempengaruhi pasokan air (Hecker dan Bilski, 2014).

\section{Karakteristik Pelindian Abu Batubara}

Dalam beberapa tahun terakhir, promosi produksi energi dari limbah dan biomassa di Uni Eropa telah menyebabkan jumlah residu pembakaran, yaitu bahan abu mengalami peningkatan yang luar biasa. Dengan tujuan menemukan cara pemanfaatan bahan abu yang efisien dan aman dari sisi lingkungan dan ekonomi merupakan hal yang penting di seluruh Eropa. Pemanfaatan harus dilakukan tanpa bahaya bagi kesehatan manusia dan lingkungan sesuai dengan undang-undang saat ini. Di Uni Eropa, peraturan baru tentang klasifikasi limbah yang diselaraskan mulai diberlakukan pada 1 Juni 2015. Pada peraturan tersebut, kriteria dan metode penilaian untuk klasifikasi limbah berbahaya diselaraskan dengan sistem lain yang disetujui secara internasional untuk klasifikasi bahaya bahan kimia dalam regulasi tentang Classification Labelling Packaging (CLP) yang mengatur pengelolaan bahaya pada perundangan bahan kimia (Stiernström $d k k_{\text {., }}$ 2011, 2014; Stiernström, Wik dan Bendz, 2016).

Di Eropa (European Economic Community (EEC), penilaian ekotoksikologi limbah merupakan persyaratan yang ada dalam peraturan. Council Directive 91/689/EEC (EEC, 1991) menyatakan adanya 14 kriteria untuk karakterisasi limbah berbahaya. Kriteria H-14 'ekotoksik' dari Annex III menjadikan 'zat dan persiapan yang menimbulkan atau dapat menimbulkan risiko segera atau tertunda untuk satu atau lebih pada sektor lingkungan', sebagai limbah berbahaya (Wilke $d k k ., 2008$ ).

Oleh karena itu di Uni Eropa, abu harus diklasifikasikan berdasarkan efek berbahaya yang melekat di bawah kriteria $\mathrm{H}-14$ (ekotoksik) dalam petunjuk tentang limbah atau The Waste Framework Directive 2008/98/EC. Namun demikian, hingga saat ini kriteria kuantitatif untuk klasifikasi yang baik untuk berbagai kondisi semacam ini belum ada, tetapi dinyatakan bahwa sistem uji biologi yang ada saat ini dapat digunakan. Kriteria dan panduan untuk penilaian bahaya ekotoksikologi (Hazard Property 14, HP-14) masih dinilai kurang untuk klasifikasi limbah. Evaluasi pada klasifikasi HP14 biasanya didasarkan pada (Stiernström, Wik dan Bendz, 2016):

- metode perhitungan berdasarkan penjumlahan untuk bahan-bahan yang berupa campuran, dan

- tes pelindian

Di Swedia, penelitian yang pernah dilakukan menggunakan abu hasil pembakaran sampah kota (bukan PLTU) dan hasilnya menunjukkan bahwa konsentrasi tinggi komponen nonberbahaya seperti $\mathrm{Ca}$ dan $\mathrm{K}$, mempengaruhi toksisitas hampir semua eluat abu, sedangkan komponen berbahaya, misal $\mathrm{Zn}$ dan $\mathrm{Pb}$, hanya mempengaruhi peringkat toksisitas eluat sebagai yang paling berbahaya. Pengujian sub tes kronis terbukti memberikan hasil yang lebih sensitif dibandingkan dengan pengujian tes akut tetapi adakalanya faktor perhitungan ekstrapolasi membuat hasil perkiraan toksisitas kronis menjadi agak berlebihan. 
Untuk dapat memahami ekotoksisitas abu lindi, perlu diketahui pula informasi rinci tentang bioavailabilitas dan spesiasi logam dalam lindi tersebut. Di samping itu, pada karakterisasi pelindian abu, beberapa parameter seperti $\mathrm{pH}$, perbandingan cairan pelindi dan abu serta ukuran partikel abu juga harus menjadi bahan pertimbangan. Parameter-parameter tersebut perlu diatur dan dijaga kesetimbangannya sebelum dilakukan pengujian ekotoksikologi lebih lanjut.

Pengujian terhadap abu dari PLTU perlu diteliti lebih lanjut karena karakteristik proses pembakaran dan bahan bakar yang dipakai akan sangat menentukan karakter abu yang dihasilkan. Percobaan yang dilakukan di Puslitbang tekMIRA lebih ditekankan pada karakterisasi kandungan logam-logam beratnya, pengujian TCLP, pengujian toksikologi secara biologi, ekstraksi tunggal dan spesiasi logamlogam berat dalam abu guna mendukung pemanfaatannya di berbagai sektor.

\section{METODE}

Di Puslitbang tekMIRA, berbagai kegiatan penelitian tentang FABA sudah dilakukan sejak 1995. Berbagai penelitian laboratorium dan pemanfaatan FABA juga sudah pernah dicoba di laboratorium Puslitbang tekMIRA. Kajian perbaharuan perlu dilakukan kembali untuk menguji ulang data perolehan yang telah lalu. Hal ini karena karakteristik batubara yang dipakai pada kurun waktu tersebut juga berbeda-beda. Kajian dalam tulisan ini merupakan gabungan dari perkembangan kajian literatur yang ada pada tahun-tahun terakhir dan kajian yang didasarkan penelitian yang pernah dilakukan dan beberapa ulasan terbaru tentang FABA yang ada di dalam ataupun luar negeri. Perkembangan pengujian yang berhubungan dengan karakterisasi dan toksikologi FABA juga menjadi pertimbangan dalam kajian ini.

\section{HASIL DAN PEMBAHASAN}

\section{Karakterisasi Abu Batubara}

Abu batubara merupakan material berpartikel halus yang dominan berbentuk spherik padat ataupun berongga. Material ini merupakan senyawa fero alumino silikat dengan unsur- unsur utama $\mathrm{Si}, \mathrm{Al}, \mathrm{Fe}, \mathrm{Ca}, \mathrm{K}$ dan $\mathrm{Na}$. Mineraloginya sangat dipengaruhi oleh batubara asalnya. Beberapa penelitian pemanfaatan abu batubara sebagai bahan penetral asam dan pengadsorp logam-logam berbahaya dalam limbah tambang telah diujicoba (Gitari $d k k ., 2008$ ).

Abu batubara diperkirakan punya alkalinitas yang tinggi karena adanya fraksi kapur di dalamnya. Namun demikian hasil analisis menunjukkan bahwa abu batubara juga mengandung bahan-bahan pencemar berupa logam-logam berat. Oleh karena itu penumpukan abu batubara di lokasi penimbunan diperkirakan akan memberikan dampak yang cukup serius di lingkungan dan pengelolaan yang kurang baik terhadap abu batubara tersebut akan mengurangi lahan produktif, mencemari tanah dan tanaman. Ada kalanya untuk pemanfaatannya, perlu dilakukan modifikasi terhadap abu batubara baik sekedar aktivasi dalam suasana asam, basa atau bahkan mengubahnya menjadi zeolit sintetik.

Puslitbang tekMIRA pada awalnya melakukan kegiatan karakterisasi abu batubara pada tahun 1988. Kegiatan ini mencakup abu batubara yang berasal dari PLTU ataupun abu yang berasal dari tungku-tungku mini yang dikembangkan oleh tekMIRA. Di samping penelitian abu batubara, juga mengkarakterisasi abu yang berasal dari batubara yang sengaja diabukan di laboratorium. Hasil karakteristik pembakaran ini menunjukkan hasil yang sangat berbeda. Namun pada makalah ini hanya dibatasi pada abu yang berasal dari sebagian PLTU di Jawa, Sumatera dan Kalimantan. Pada dasarnya PLTU di Jawa menggunakan batubara yang berasal dari Sumatera dan Kalimantan. Kadar abu dalam batubara Indonesia sangat bervariasi besarannya yaitu berkisar dari 1 $17 \%$. Pada dasarnya komposisi abu batubara Indonesia juga didominasi oleh oksida-oksida seperti $\mathrm{SiO}_{2}, \mathrm{Al}_{2} \mathrm{O}_{3}, \mathrm{CaO}, \mathrm{SO}_{3}$, dan $\mathrm{Fe}_{2} \mathrm{O}_{3}$. Abu batubara juga mengandung logam-logam berat seperti $\mathrm{Mn}, \mathrm{Pb}, \mathrm{Cu}, \mathrm{Zn}, \mathrm{Cd}, \mathrm{Cr}, \mathrm{Co}, \mathrm{Hg}$, Se, V dan As. Umumnya, di Indonesia abu batubara diklasifikasikan dalam kelas $\mathrm{C}$ dan $\mathrm{F}$. Pengklasifikasian abu ini tidak dapat dilakukan secara tepat mengingat batubara Indonesia yang digunakan di PLTU berasal dari jenis lignit dan bituminus yang adakalanya pada saat dipakai sebagai bahan bakar merupakan campuran kedua jenis batubara tersebut. 
Oleh karena abu batubara dikategorikan sebagai limbah B3 maka sebelum melakukan penelitian pemanfaatannya, perlu pengujian karakteristiknya. Laboratorium Puslitbang tekMIRA bersama laboratorium Pusat Penelitian Sumber Daya Alam dan Lingkungan (PPSDAL) - Universitas Padjadjaran (Unpad) melakukan penelitian toksisitas abu batubara secara kimia maupun biologi dan juga penelitian keterlindian logam berat yang terkandung di dalamnya. Beberapa pengujian toksikologi ini menunjukkan bahwa abu batubara yang diteliti dapat dikategorikan sebagai bukan limbah B3.

Komposisi mineral abu batubara Indonesia yang diuji pada penelitian ini menunjukkan abu batubara terdiri dari kuarsa, mulit, plagioklas dan kristobalit dengan komposisi oksida yang dominan adalah silika dan alumina. Karakterisasi terhadap abu batubara terutama dilihat pada kandungan unsur-unsur mayor dan minornya. Komposisi mineralnya tersebut yang ditentukan dengan menggunakan XRD, menunjukkan bahwa abu batubara mengandung kuarsa, mulit, plagioklas dan kristobalit (Tabel 4).
Konsentrasi elemen mayor $\mathrm{CaO}, \mathrm{MgO}, \mathrm{K}_{2} \mathrm{O}$ dan $\mathrm{Na}_{2} \mathrm{O}$ dalam abu terbang dan abu dasar PLTU Jawa Timur dan Jawa Barat ada sedikit perbedaan. Konsentrasi $\mathrm{CaO}$ pada abu terbang hampir dua kali lipat dari konsentrasinya pada abu dasar sedangkan konsentrasi $\mathrm{MgO}$ dan $\mathrm{Na}_{2} \mathrm{O}$ pada kedua jenis abu tersebut hampir sama. Konsentrasi $\mathrm{K}_{2} \mathrm{O}$ pada abu terbang hanya setengah dari konsentrasi oksida alkali tanah tersebut dalam abu dasar (Tabel 5). Hal yang sama juga ditemukan pada PLTU di Kalimantan. Konsentrasi $\mathrm{CaO}$ pada abu terbang hampir dua kali lipat dari konsentrasinya pada abu dasar berbeda dengan PLTU Sumatera, sedangkan konsentrasi $\mathrm{MgO}$ dan $\mathrm{K}_{2} \mathrm{O}$ pada kedua jenis abu tersebut hampir sama. Konsentrasi $\mathrm{Na}_{2} \mathrm{O}$ pada abu terbang hampir lima kali dari konsentrasi oksida alkali tanah tersebut dalam abu dasar. Perbedaan komposisi ini diperkirakan dapat disebabkan oleh kondisi operasional teknologi pembakaran di PLTU ataupun sistem kontrol pencemaran udara pada cerobong PLTU. Pembakaran yang belum sempurna menyebabkan oksida unsur-unsur mayor dalam abu dasar diperkirakan lebih kecil dari yang ada dalam abu terbang (Miod, 2008; Lam dkk., 2010; Mal'chik, Litovkin dan Rodionov, 2015).

Tabel 4. Hasil pengujian XRD contoh abu batubara (Damayanti, Untung dan Sahminan, 2004)

\begin{tabular}{llcccccc}
\hline \multirow{2}{*}{ Komposisi Mineral } & \multicolumn{2}{c}{ Rumus Kimia } & \multicolumn{3}{c}{ Kalimantan } & \multicolumn{3}{c}{ Sumatera } \\
\cline { 2 - 7 } & $\mathrm{SiO}_{2}$ & $\mathrm{DF}$ & $\mathrm{FA}$ & $\mathrm{BA}$ & $\mathrm{DF}$ & $\mathrm{FA}$ & $\mathrm{BA}$ \\
\hline Kuarsa & $\mathrm{Al}$ & $\mathrm{x}$ & $\mathrm{x}$ & $\mathrm{x}$ & $\mathrm{x}$ & $\mathrm{x}$ \\
Mulit & $\mathrm{Al}_{6} \mathrm{Si}_{2} \mathrm{O}_{13}$ & $\mathrm{x}$ & $\mathrm{x}$ & $\mathrm{x}$ & $\mathrm{x}$ & $\mathrm{x}$ \\
Plagioklas & $(\mathrm{Na}, \mathrm{Ca}) \mathrm{Al}\left(\mathrm{Al}, \mathrm{Si}_{1} \mathrm{Si}_{2} \mathrm{O}_{8}\right.$ & & & $\mathrm{x}$ & & & \\
Kristobalit & $\mathrm{SiO}_{2}$ & & & & & $\mathrm{x}$ \\
\hline
\end{tabular}

Catatan: $\mathrm{x}$ : komposisi mineral yang terdeksi dalam contoh

Tabel 5. Komposisi kimia mayor dalam abu batubara (Damayanti, Untung dan Sahminan, 2004)

\begin{tabular}{|c|c|c|c|c|c|c|c|c|}
\hline \multirow{3}{*}{ No. } & \multirow{3}{*}{$\begin{array}{l}\text { Komposisi } \\
\text { Kimia }\end{array}$} & \multirow{3}{*}{ Satuan } & \multicolumn{6}{|c|}{ Abu Batubara dari PLTU } \\
\hline & & & \multicolumn{3}{|c|}{ Jawa Timur } & \multicolumn{3}{|c|}{ Jawa Barat } \\
\hline & & & $\mathrm{DA}$ & $\mathrm{FA}$ & $\mathrm{BA}$ & $\mathrm{DA}$ & FA & $\mathrm{BA}$ \\
\hline 1. & $\mathrm{SiO}_{2}$ & $\%$ & 41,2 & 41,3 & 51,1 & 49,5 & 51,3 & 62,2 \\
\hline 2. & $\mathrm{Al}_{2} \mathrm{O}_{3}$ & $\%$ & 29,5 & 29,5 & 17,94 & 20,55 & 34,6 & 25,5 \\
\hline 3. & $\mathrm{TiO}_{2}$ & $\%$ & 1,30 & 1,25 & 1,36 & 1,11 & 0,13 & 0,13 \\
\hline 4. & $\mathrm{Fe}_{2} \mathrm{O}_{3}$ & $\%$ & 13,53 & 11,55 & 11,95 & 4,49 & 5,11 & 5,25 \\
\hline 5. & $\mathrm{CaO}$ & $\%$ & 8,11 & 9,13 & 4,78 & 3,13 & 4,48 & 2,37 \\
\hline 6. & $\mathrm{MgO}$ & $\%$ & 2,15 & 2,46 & 1,98 & 1,54 & 1,81 & 1,20 \\
\hline 7. & $\mathrm{~K}_{2} \mathrm{O}$ & $\%$ & 0,99 & 1,14 & 2,83 & 0,48 & 0,48 & 0,33 \\
\hline 8. & $\mathrm{Na}_{2} \mathrm{O}$ & $\%$ & 1,36 & 1,73 & 1,09 & 2,16 & 0,69 & 0,44 \\
\hline 9. & $\mathrm{MnO}_{2}$ & $\%$ & 0,053 & 0,038 & 0,083 & 0,089 & 0,20 & 0,18 \\
\hline 10. & $\mathrm{SO}_{3}$ & $\%$ & 0,72 & 0,82 & 0,25 & 14,18 & $\mathrm{tt}$ & $\mathrm{tt}$ \\
\hline 11. & $\mathrm{P}_{2} \mathrm{O}_{5}$ & $\%$ & 0,29 & 0,24 & 0,27 & 0,57 & - & - \\
\hline
\end{tabular}




\begin{tabular}{|c|c|c|c|c|c|c|c|c|}
\hline \multirow{3}{*}{ No. } & \multirow{3}{*}{$\begin{array}{c}\text { Komposisi } \\
\text { Kimia }\end{array}$} & \multirow{3}{*}{ Satuan } & \multicolumn{6}{|c|}{ Abu Batubara dari PLTU } \\
\hline & & & \multicolumn{3}{|c|}{ Jawa Timur } & \multicolumn{3}{|c|}{ Jawa Barat } \\
\hline & & & DA & FA & $\mathrm{BA}$ & DA & $\mathrm{FA}$ & BA \\
\hline 12. & LOI & $\%$ & 0,61 & 0,62 & 6,22 & 2,08 & 0,45 & 2,16 \\
\hline 13. & $\mathrm{SiO}_{2}$ & $\%$ & 57,2 & 63,3 & 62,8 & 55,58 & 44,4 & 87,8 \\
\hline 14. & $\mathrm{Al}_{2} \mathrm{O}_{3}$ & $\%$ & 26,5 & 22,4 & 21,0 & 18,97 & 27,0 & 4,43 \\
\hline 15. & $\mathrm{TiO}_{2}$ & $\%$ & 0,92 & 1,01 & 1,06 & 1,02 & 1,44 & 0,27 \\
\hline 16. & $\mathrm{Fe}_{2} \mathrm{O}_{3}$ & $\%$ & 5,10 & 6,26 & 5,81 & 14,26 & 15,84 & 5,47 \\
\hline 17. & $\mathrm{CaO}$ & $\%$ & 3,30 & 1,97 & 2,27 & 1,38 & 3,49 & 0,15 \\
\hline 18. & $\mathrm{MgO}$ & $\%$ & 1,89 & 1,19 & 1,37 & 1,16 & 2,32 & 0,30 \\
\hline 19. & $\mathrm{~K}_{2} \mathrm{O}$ & $\%$ & 0,57 & 0,33 & 0,36 & 0,66 & 0,68 & 0,36 \\
\hline 20. & $\mathrm{Na}_{2} \mathrm{O}$ & $\%$ & 1,63 & 0,66 & 0,95 & 0,71 & 0,17 & 0,094 \\
\hline 21. & $\mathrm{MnO}_{2}$ & $\%$ & 0,079 & 0,068 & 0,068 & 0,17 & 0,22 & 0,046 \\
\hline 22. & $\mathrm{SO}_{3}$ & $\%$ & 0,46 & 0,36 & 0,12 & 0,37 & 0,67 & 0,089 \\
\hline 23. & $\mathrm{P}_{2} \mathrm{O}_{5}$ & $\%$ & 0,55 & 0,25 & 0,23 & 0,09 & 0,11 & $\mathrm{tt}$ \\
\hline 24. & LOI & $\%$ & 1,60 & 2,04 & 3,76 & 3,68 & 3,43 & 0,69 \\
\hline Catatan: & $\begin{array}{ll}\text { DA } & : \text { Lokas } \\
\text { FA } & : \text { Abu } \\
\text { BA } & : \text { Abu } \\
\mathrm{tt} & : \text { Tidak }\end{array}$ & $\begin{array}{l}\text { nimbuna } \\
\text { ang } \\
\text { r leteksi }\end{array}$ & & an BA) & & & & \\
\hline
\end{tabular}

Pada umumnya abu batubara PLTU Jawa Timur dan Jawa Barat mengandung unsur-unsur logam berat yang hampir sama seperti $\mathrm{Fe}, \mathrm{Zn}, \mathrm{Ni}, \mathrm{Cr}$, $\mathrm{Co}, \mathrm{Cu}$ dan $\mathrm{Pb}$ yang disusun berdasarkan urutan konsentrasi dari besar ke kecil. Jenis unsur logam berat yang diperoleh dalam abu tersebut hampir sama, hanya komposisinya dalam abu PLTU asal Jawa Timur lebih tinggi dari PLTU Jawa Barat. Kondisi ini menyerupai abu asal PLTU di Kalimantan dan PLTU di Sumatera. Hal ini diduga berkaitan dengan asal batubara yang dipakai. PLTU di Jawa Timur pada umumnya menggunakan batubara asal Kalimantan dan PLTU di Jawa Barat memanfaatkan batubara asal Sumatera. Abu batubara PLTU Jawa Barat pun mengandung unsur-unsur logam berat seperti $\mathrm{Fe}, \mathrm{Zn}, \mathrm{Ni}, \mathrm{Cr}, \mathrm{Co}, \mathrm{Cd}$ dan $\mathrm{Cu}$ yang bervariasi tetapi $\mathrm{Pb}$ tidak ditemukan dalam ketiga jenis abu tersebut. Logam Fe yang ditentukan pada percobaan ini merupakan $\mathrm{Fe}^{3+}$, yang peleburannya menggunakan campuran dari HF$\mathrm{HClO}_{4}-\mathrm{HNO}_{3}$. Logam As belum dapat ditentukan dalam pengujian ini (Tabel 6).

\section{Toxicity Characteristic Leaching Procedure (TCLP)}

Pengujian TCLP terhadap abu batubara dengan pengekstrak standar tidak menunjukkan terjadinya pelindian logam berat. Hal ini menunjukkan bahwa abu batubara yang dipakai dalam penelitian tersebut dikategorikan sebagai bahan yang tidak berbahaya dan beracun (Tabel 7).
Apabila FABA akan dimanfaatkan untuk mengelola limbah air asam tambang maka sebaiknya dilakukan pula pengujian dengan menggunakan air asam tambang sebagai pengekstraknya untuk melihat kondisi pelindiannya.

\section{Ekstraksi Tunggal Logam-logam Berat}

Percobaan ini dilakukan guna mengantisipasi kemungkinan terjadinya pelindian logam-logam berat dari lokasi penimbunan FABA. Menurut Lokeshappa dan Dikshit (2012), penilaian risiko lingkungan terhadap hal-hal yang berkaitan dengan pengelolaan dan pembuangan FABA merupakan persoalan penting. FABA mengandung logam beracun yang dapat dilepaskan ke lingkungan baik pada saat proses pembakaran dan pencucian batubara ataupun pada saat pembuangan, penyimpanan basah dan pemanfaatannya kembali.

Evaluasi waktu pelindian untuk lepasnya logam beracun dan logam lain yang ada dalam abu terbang asal India dengan menggunakan prosedur ekstraksi tunggal tersebut menunjukkan bahwa waktu optimum agitasi adalah 4 jam apabila menggunakan air dan pelarut untuk pertukaran ion. Sedangkan untuk penggunaan pelarut asam dan bersifat pereduksi, waktu optimumnya mencapai 24 jam agitasi. 


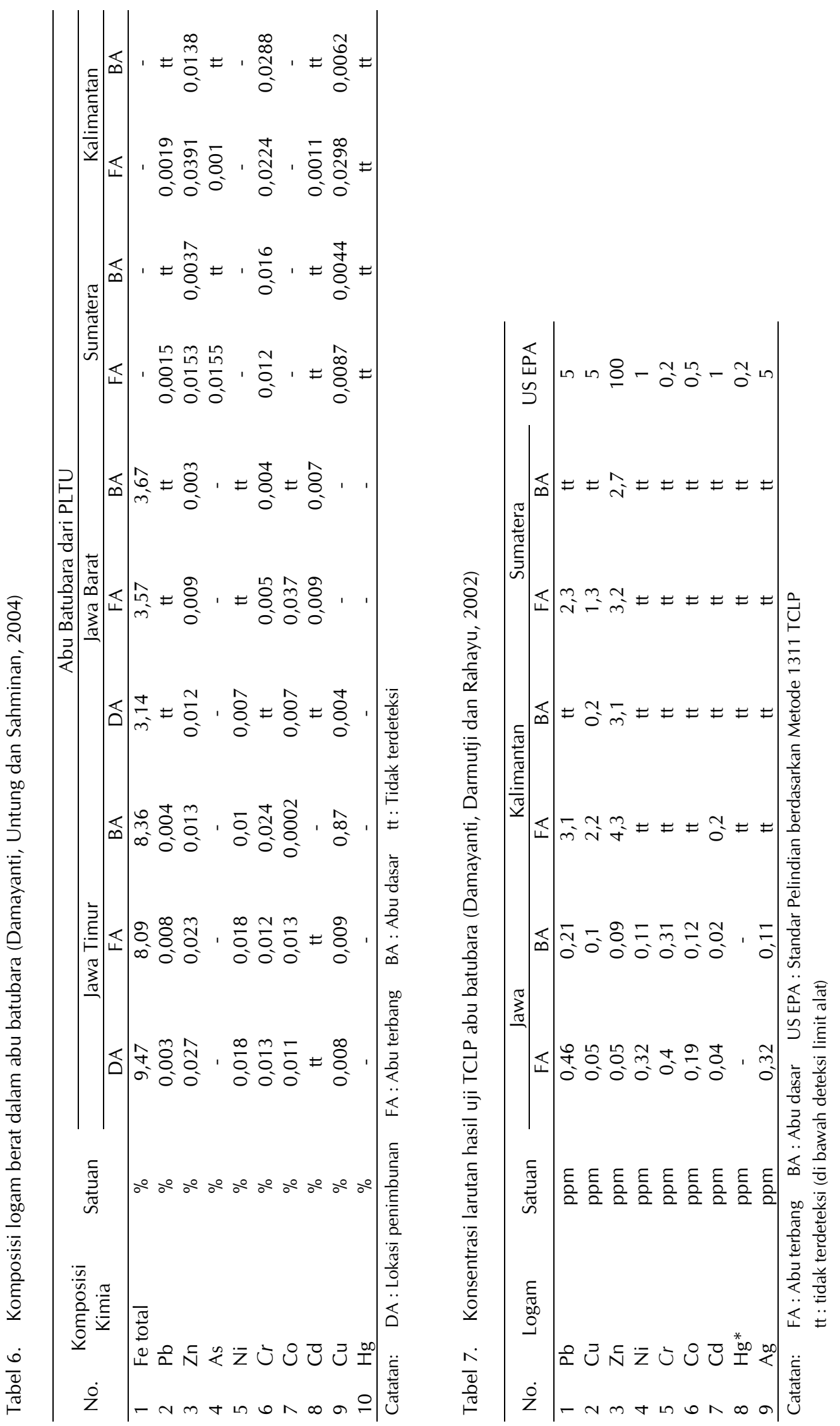


Pengujian keterlindian ini dilakukan dengan asumsi bahwa logam berat dalam FABA dapat terlindi pada kondisi reduksi dan oksidasi yang berbeda-beda, sehingga beberapa tes dengan berbagai pereaksi tunggal diujicobakan (Damayanti, Rahayu dan Darmutji, 2005).

Logam-logam seperti $\mathrm{Fe}, \mathrm{Mn}, \mathrm{Pb}, \mathrm{Cu}, \mathrm{Zn}, \mathrm{Cd}$, $\mathrm{Cr}, \mathrm{Co}, \mathrm{Ni}$ dan $\mathrm{Ag}$ dalam FABA dapat ditemukan dalam fraksi yang terlarut dalam air dengan $\mathrm{pH}$ pada nilai 7 - 8 maupun pada pelarut yang bersifat sebagai oksidator kuat sepert $\mathrm{HNO}_{3}$ dan $\mathrm{H}_{2} \mathrm{O}_{2}$ serta pelarut yang bersifat basa seperti $\mathrm{NaOH}$ (Gambar 3). Keterlindian logam-logam ini selama 2 jam berada di bawah $10 \%$ dari konsentrasinya yang terdapat dalam FABA nya (Damayanti, Darmutji dan Rinaldi, 2006).

\section{Spesiasi Logam-logam Berat}

Pada percobaan spesiasi logam berat dalam abu batubara diketahui bahwa umumnya unsur-unsur logam pada percontoh abu dasar yang diuji menunjukkan terikat kuat pada fraksi residu (31,57 - 80,33\%), fraksi organik $(0-52,02 \%)$ dan fraksi oksida Fe-Mn (0 $36,80 \%)$. Sedangkan unsur-unsur logam tersebut hanya sedikit yang terikat pada fraksi karbonat $(0,07-12,84 \%)$ dan fraksi yang dapat dipertukarkan $(0-28,78 \%)$. Hal yang sama terjadi pada percontoh abu terbang, unsur-unsur logam yang diuji juga menunjukkan terikat kuat pada fraksi residu $(44,49$ - 76,74 \%), fraksi organik (1,80 $24,76 \%)$ dan fraksi oksida Fe-Mn (2,30 $33,40 \%$ ). Unsur-unsur logam tersebut juga sedikit yang terikat pada fraksi karbonat $(0,03$ - 10,75 \%) dan fraksi yang dapat dipertukarkan $(0,10 \quad-13,92 \%)$ seperti diperlihatkan pada Tabel 8.

Pada kondisi ini, kemungkinan terjadinya pencemaran dari unsur-unsur logam tersebut dapat dianggap tidak akan terlalu berpengaruh karena logam-logam seperti $\mathrm{Fe}, \mathrm{Mn}, \mathrm{Pb}, \mathrm{Cu}$, $\mathrm{Zn}$ dan $\mathrm{Cd}$ telah ada secara alami pada struktur kristal mineral primer dan sekundernya, sehingga pada keadaan normal logam-logam tersebut tidak akan dengan mudah dilepaskan di alam.

Banyaknya unsur-unsur logam dalam abu terbang dan abu dasar yang terdistribusi dalam fraksi oksida Fe-Mn, fraksi organik dan fraksi residu mengakibatkan unsur-unsur tersebut tidak terlalu membahayakan di lingkungan dalam arti kemungkinannya terlindi sangat kecil.

\section{Karakteristik Toksisitas Akut}

Pada percobaan toksisitas akut, abu batubara yang dipakai adalah abu batubara dari PLTU di Sumatera dan Kalimantan. Salah satu bentuk dari pengujian biologi adalah uji toksisitas akut yang dinyatakan dalam konsentrasi letal (Lethal Concentration/LC) atau dosis letal (Lethal Dose/LD). LC dan LD merupakan salah satu cara untuk mengukur potensi racun suatu bahan dalam waktu pendek. Konsentrasi letal biasanya menyatakan konsentrasi kimia di udara tetapi dalam kajian lingkungan dapat juga menyatakan konsentrasi kimia dalam air. LC dan LD bisa dinyatakan dalam kisaran 0 100, namun yang umum dipakai adalah angka 50. Dengan demikian, LC50 menyatakan konsentrasi kimia di udara/air yang dapat menyebabkan kematian 50 \% dari kelompok hewan uji dalam jangka waktu tertentu, biasanya dalam 48 - 96 jam (Hadijah, Khaerunnisa dan Untung, 2006).

Pengamatan dilakukan selama 21 hari, kemudian total neonate Daphnia carinata King yang ditetaskan dihitung. Hasil penelitian menunjukkan, nilai LC50 - 48 jam adalah pada kisaran 64.980 - 70.000 ppm untuk abu terbang (FA) dan 77.729 - 89.350 ppm untuk abu dasar (BA). Nilai ini berada pada kisaran 10,000 hingga 100,000 ppm, yang berarti masuk pada kriteria hampir tidak toksik (Tabel 9). Hal ini menunjukkan bahwa larutan uji yang berasal dari FABA dikategorikan dalam kriteria hampir tidak toksik. Analisis data varians terhadap tingkat reproduksi Daphnia carinata King pada tingkat kepercayaan 0,05 dan hasil perhitungan Anava menunjukkan bahwa masing-masing larutan uji dapat menurunkan tingkat reproduksi maupun pertumbuhan (panjang) neonate Daphnia carinata King.

Pengujian toksisitas akut LD50 juga dilakukan terhadap hewan mencit (Mus musculus) Swiss webster dengan kombinasi dosis yang berbeda-beda. Pengamatan selama 14 hari untuk melihat efek terlambat menunjukkan bahwa kematian yang terjadi kurang dari 50\% 
baik untuk mencit jantan ataupun betina (Tabel 10). Nilai toksisitas LD50 untuk FA ada pada kisaran 18.352 - 62.025,7 ppm dan untuk BA pada kisaran 21-429 - 29.855,6 ppm. Mengacu pada PP no. 74/2001, FABA yang dipakai pada penelitian ini termasuk dalam kategori bahan yang relatif tidak berbahaya (Khaerunnisa, Hadijah dan Damayanti, 2006).

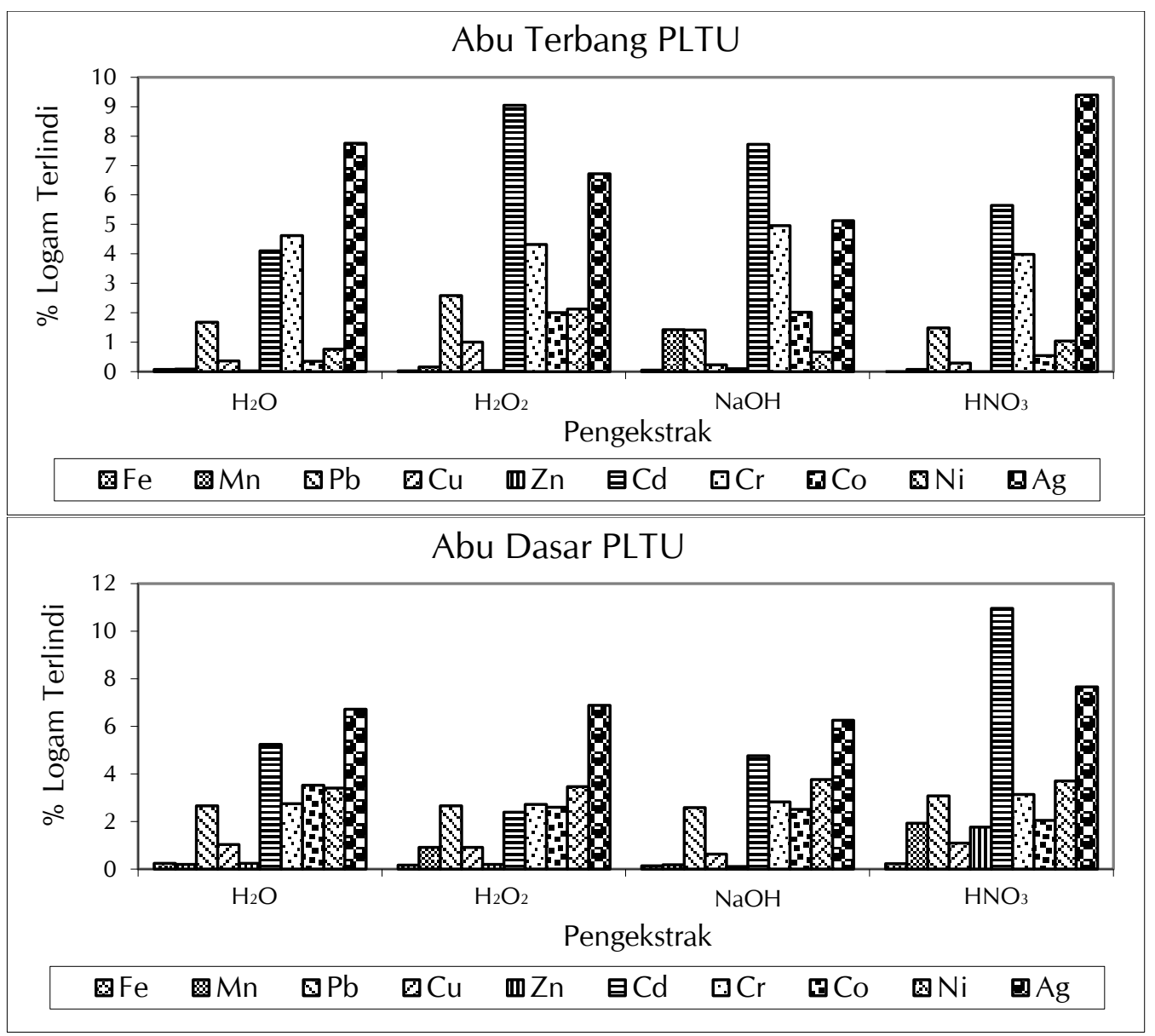

Gambar 3. Keterlindian logam berat dalam berbagai pelarut

Tabel 8. Komposisi unsur-unsur logam dalam tiap fraksi dari percobaan ekstraksi bertahap (Damayanti dan Darmutji, 2003)

\begin{tabular}{|c|c|c|c|c|c|c|c|c|c|c|c|}
\hline \multirow{3}{*}{$\begin{array}{l}\text { Unsur } \\
\text { Logam }\end{array}$} & \multirow{3}{*}{ Satuan } & \multicolumn{10}{|c|}{ Contoh } \\
\hline & & \multicolumn{5}{|c|}{ Abu Terbang } & \multicolumn{5}{|c|}{ Abu Dasar } \\
\hline & & EXC & CAR & OX & ORG & RES & EXC & CAR & OX & ORG & RES \\
\hline $\mathrm{Fe}$ & $\%$ & 0,13 & 0,03 & 21,30 & 1,80 & 76,74 & 0,31 & 0,07 & 16,94 & 2,35 & 80,33 \\
\hline$M n$ & $\%$ & 0,33 & 0,22 & 33,40 & 8,76 & 57,28 & 0,57 & 0,79 & 18,32 & 3,24 & 77,08 \\
\hline $\mathrm{Pb}$ & $\%$ & 11,49 & 6,02 & 11,85 & 5,47 & 65,18 & 28,78 & 6,47 & 0,00 & 0,00 & 64,75 \\
\hline $\mathrm{Cu}$ & $\%$ & 0,10 & 0,08 & 2,30 & 24,76 & 72,76 & 0,00 & 0,18 & 15,57 & 36,80 & 47,44 \\
\hline $\mathrm{Zn}$ & $\%$ & 0,68 & 0,55 & 29,59 & 8,81 & 60,37 & 1,97 & 7,97 & 52,02 & 6,47 & 31,57 \\
\hline $\mathrm{Cd}$ & $\%$ & 13,92 & 10,75 & 23,35 & 7,49 & 44,49 & 20,97 & 12,84 & 5,24 & 17,69 & 43,25 \\
\hline \multicolumn{12}{|c|}{ Keterangan: } \\
\hline EXC & (Fraksi-1) & : Dapat dip & ertukark & & & & & & & & \\
\hline CAR & (Fraksi-2) & : Terikat $\mathrm{p}$ & da karb & & & & & & & & \\
\hline OX & (Fraksi-3) & : Terikat $\mathrm{p}$ & da oksic & Fe-Mn & & & & & & & \\
\hline ORG & (Fraksi-4) & : Terikat $\mathrm{p}$ & da mate & al organik & & & & & & & \\
\hline RES & (Fraksi-5) & : Residu & & & & & & & & & \\
\hline
\end{tabular}


Tabel 9. Kriteria tingkat toksisitas LC50 (Hadijah, Khaerunnisa dan Untung, 2006)

\begin{tabular}{ccc}
\hline Kriteria & Keterangan Toksisitas & Nilai (ppm) \\
\hline 1. & Sangat toksik & $<1$ \\
2. & Toksik & $1-100$ \\
3. & Daya racun sedang & $100-1.000$ \\
4. & Daya racun rendah/sedikit & $1,000-10.000$ \\
5. & Hampir tidak toksik & $10.000-100.000$ \\
6. & Tidak toksik & $>100.000$ \\
\hline
\end{tabular}

Tabel 10. Kriteria tingkat toksisitas LD50 (Khaerunnisa, Hadijah dan Damayanti, 2006)

\begin{tabular}{ccc}
\hline Kriteria & Keterangan Toksisitas & Nilai (ppm) \\
\hline 1. & Amat sangat beracun & $\leq 1$ \\
2. & Sangat beracun & $1-50$ \\
3. & Beracun & $51-500$ \\
4. & Agak beracun & $501-5.000$ \\
5. & Praktis tidak beracun & $5.001-15.000$ \\
6. & Realtif tidak berbahaya & $>15.000$ \\
\hline
\end{tabular}

\section{Penelitian Pemanfaatan FABA di tekMIRA}

Pemanfaatan faba di luar negeri sudah banyak diketahui, terutama di negara-negara seperti India, Cina, AS yang banyak menggunakan batubara sebagai sumber energi. Di Indonesia, kajian pemanfaatan abu batubara terutama yang terkait dengan pertambangan perlu terus dikembangkan dengan pengujian-pengujian yang lebih detail guna melihat efek samping pemanfaatannya. Puslitbang tekMIRA telah melakukan beberapa uji pemanfaatan abu batubara, di antaranya sebagai pembenah lahan dan media tanam dalam revegetasi lahan bekas tambang, bahan refraktori cor, bahan pembuatan bata dan mortar, pengolah limbah air asam tambang, material penimbun pada lahan reklamasi, serta sebagai campuran pada red mud untuk pembuatan material geopolimer.

Lahan bekas tambang umumnya mengalami gangguan pada keseimbangan ekosistem permukaan tanahnya terutama dalam kualitas kesuburan lahannya. Untuk mengatasi masalah tersebut, abu batubara dapat dimanfaatkan sebagai bahan pembenah lahan (soil conditioner) dengan pertimbangan bahwa secara kimia abu batubara mengandung unsur-unsur makro seperti Fe, $\mathrm{Ca}, \mathrm{Al}, \mathrm{Si}, \mathrm{K}$ dan Mg dengan persentase tinggi, dan mengandung unsur-unsur mikro seperti Zn, B, Mn dan Cu dalam jumlah sedang, serta sejumlah kecil unsur $\mathrm{C}$ dan $\mathrm{N}$ yang terdapat dalam bentuk silikat, oksida, sulfat dan karbonat. Pada kajian ini penambahan kompos sebagai sumber bahan organik dalam campuran abu batubara, yang berasal dari PLTU Asam-asam dan PLTU Bukit Asam, tetap perlu dilakukan untuk membantu menstimulasi mikroorganisme dalam tanah untuk pertumbuhan tanaman. Dalam kajian ini terlihat pula bahwa abu batubara memiliki potensi menurunkan tingkat keasaman tanah pada lahan bekas tambang (Hadijah dan Damayanti, 2006; Kurniawan, Surono dan Alimano, 2014).

Keperluan refraktori cor dan bahan bakunya cenderung meningkat dan sampai saat ini masih dipenuhi melalui impor. Salah satu bahan refraktori yang masih diimpor adalah mulit yang banyak ditemukan dalam abu terbang. Berdasarkan penelitian, abu batubara dari PLTU Suralaya secara teknis mempunyai prospek untuk dipakai sebagai komponen bahan baku refraktori cor (Aziz, Ardha dan Tahli, 2006).

Pemanfaaatan abu batubara untuk pengelolaan limbah tambang, dalam hal ini air asam tambang juga pernah diujicobakan. Percontoh abu batubara diambil dari PLTU di Suralaya, Paiton dan Asam-asam, sedangkan percontoh limbah cair yang bersifat asam diambil dari lokasi pertambangan batubara di Sumatera Selatan. Penelitian ini dilakukan pada skala laboratorium. Dalam kegiatan ini abu batubara dapat menaikkan $\mathrm{pH}$ air asam tambang (AAT) dan mengabsorb logam-logam 
berat seperti $\mathrm{Pb}, \mathrm{Cu}, \mathrm{Zn}, \mathrm{Ni}, \mathrm{Cr}$, Co yang terdapat dalam limbah aat (Damayanti dan Darmutji, 2002).

Abu batubara sebagai material penimbun pada lahan reklamasi juga telah dikaji meskipun masih pada skala laboratorium. Aplikasi di lapangan perlu waktu agak panjang karena memerlukan tidak hanya izin penelitian tetapi juga izin untuk uji coba di lapangan (Kurniawan $d k k ., 2010$ ).

Geopolimer, yang banyak digunakan sebagai bahan bangunan berbentuk batu bata, adalah bahan yang dihasilkan dari proses geosintesis partikel polimer aluminosilikat dan alkali silikat. Abu batubara pada pembuatan material geopolimer digunakan dalam campuran bersama red mud. Fasa yang terbentuk dalam pencampuran ini memiliki tekstur yang cocok untuk bahan geopolimer dan nilai kuat tekan material geopolimer yang terbentuk sudah memenuhi pesyaratan SNI yang ditetapkan untuk bahan bangunan (Aziz dan Azhari, 2014).

Pada saat ini yang sedang dalam tahap perancangan penelitian adalah pemanfaatan FABA dan implementasinya di lapangan untuk bahan dasar jalan (road base), pupuk dan material penutup (encapsulation material) pada batuan-batuan pembentuk asam (acid forming rocks) di lokasi tambang Pemanfaatan sebagai bahan baku semen dapat menjadi alternatif terutama apabila proses pembakaran di PLTU berlangsung dengan baik. Proses yang kurang baik pada PLTU mengakibatkan FABA perlu proses tambahan untuk dipakai sebagai bahan baku semen, seperti menghilangkan sisa $\mathrm{C}$ yang masih ada dalam bahan FABA.

\section{KESIMPULAN DAN SARAN}

Untuk mendukung program pemerintah dalam pemanfaatan batubara sebagai sumber energi pada PLTU 35 GW, maka kajian abu batubara ini perlu diperbaharui kembali dengan pengujian-pengujian yang lebih detail guna melihat efek samping pemanfaatan FABA yang dikategorikan sebagai limbah B3. Pemanfaatan abu batubara secara masif perlu dipertimbangkan dengan cukup teliti mengingat abu batubara dikategorikan sebagai bahan berbahaya dan beracun. Pemanfaatan masif ini akan dapat dilakukan terutama bila FABA dipakai sebagai material konstruksi atau bahan bangunan. Namun demikian dengan melihat sifat-sifat kimia abu batubara, dapat diketahui bahwa pemanfaatan lain secara masif di lingkungan penambangan masih dimungkinkan.

Abu batubara dapat pula dimanfaatkan baik sebagai bahan penetral limbah air asam tambang yang sekaligus berfungsi sebagai pengabsorb logam-logam berat yang ada dalam limbah tersebut maupun sebagai bahan pembenah tanah di lokasi pertambangan. Namun demikian pada pemanfaatan ini masih perlu kajian secara detail terkait keekonomian mengingat untuk bahan penetral dan pengabsorb, kebutuhan abu diperkirakan akan cukup besar yakni mencapai $10 \%$ abu batubara per liter limbah.

Pengujian terkait sifat toksik secara kimia menunjukkan bahwa pada percobaan skala laboratorium, abu batubara dari PLTU di Jawa Timur dan Jawa Barat dapat dikategorikan sebagai bukan limbah B3. Pengujian pelindian dalam berbagai kondisi redoks juga menunjukkan tidak terjadinya pelindian logam berat yang signifikan. Logam-logam berat dalam abu batubara pada pengujian spesiasi menunjukkan bahwa logam-logam ini terdistribusi pada fraksi oksida dan residu yang secara kimia mengakibatkan logamlogam tersebut tidak mudah terlindi. Walaupun demikian, monitoring yang ketat perlu dilakukan terhadap logam-logam berat yang ada dalam abu batubara sebagai antisipasi.

Dengan pemanfaatan FABA dunia saat ini yang ada pada kisaran $10-30 \%$ terutama sebagai bahan tambahan dan bahan pengisi pada material konstruksi beton semen, maka perlu pemanfaatan yang lebih terintegrasi. Pemanfaatan terintegrasi memiliki prospek signifikan baik pada penghematan energi maupun pada pengurangan emisi gas rumah kaca.

Penelitian ini perlu koordinasi kuat antar sektor sehingga dukungan dan izin dari sektor lain perlu ada kemudahan untuk kelancaran pemanfaatan abu batubara secara masif. 


\section{UCAPAN TERIMA KASIH}

Penulis mengucapkan terima kasih kepada Personil dan Manajemen Laboratorium Puslitbang tekMIRA, Laboratorium PPSDAL Unpad dan para peneliti di Puslitbang tekMIRA yang telah memberikan kontribusi pemikiran terkait pemanfaatan FABA dan penelitian pendukungnya.

\section{DAFTAR PUSTAKA}

Aziz, M., Ardha, N. and Tahli, L. (2006) "Karakterisasi abu terbang PLTU Suralaya dan evaluasinya untuk refraktori cor," Jurnal Teknologi Mineral dan Batubara, 36(14), pp. 1-8.

Aziz, M. and Azhari (2014) "Pembuatan bahan geopolimer berbasis residu bauksit untuk bahan bangunan," Jurnal Teknologi Mineral dan Batubara, 10(1), pp. 32-43. Available at: http://jurnal.tekmira.esdm.go.id/index.php/mi nerba/article/view/749.

BAPPENAS (2016) Kajian ketercapaian target DMO batubara sebesar $60 \%$ produksi nasional pada tahun 2019. BAPPENAS. Available at:

https://www.bappenas.go.id/files/5415/0898/ 5954/Laporan Akhir_Kajian DMO Batubara Final.pdf.

Damayanti, R. and Darmutji, S. T. (2002) "Pemanfaatan abu batubara asal PLTU Tanjung Enim untuk pengolahan air asam tambang," Bahan Galian Industri, 6(17), pp. $25-29$.

Damayanti, R. and Darmutji, S. T. (2003) "Penentuan fraksi-fraksi logam dalam abu batubara dengan cara ekstraksi bertahap," in Prosiding Seminar Nasional VI Kimia dalam Pembangunan, pp. 391-397.

Damayanti, R., Darmutji, S. T. and Rahayu, D. H. (2002) "Penentuan logam-logam dalam abu batubara dan uji TCLP-nya dengan metode spektrometri," in Prosiding Seminar Nasional V Kimia dalam Pembangunan, pp. 276-281.

Damayanti, R., Darmutji, S. T. and Rinaldi, A. A. (2006) "Pengaruh perubahan derajat keasaman terhadap pelindian logam-logam Fe $\mathrm{Mn} \mathrm{Pb}$ dan $\mathrm{Cd}$ dari ampas pengolahan sianidasi emas," in Prosiding Indonesian Chemistry on Science and Technology, pp. 71-74.
Damayanti, R., Rahayu, D. H. and Darmutji, S. T. (2005) "Leachability of metals from coal ash using batch system extraction," Indonesian Mining Journal, 8(3), pp. 20-24.

Damayanti, R., Untung, S. R. and Sahminan, S. (2004) "Pengujian abu terbang/fly ash (limbah B3 dalam PP No, 85/1999)," Mineral dan Batubara, 2(2), pp. 29-34.

Direktorat Jenderal Ketenagalistrikan (2016) Statistik ketenagalistrikan 2015. Jakarta: Direktorat Jenderal Ketenagalistrikan. Available at:

http://www.djk.esdm.go.id/pdf/Buku Statistik Ketenagalistrikan/Statistik Ketenagalistrikan T.A. 2016.pdf.

Direktorat Jenderal Mineral dan Batubara (2018) Laporan kinerja 2017. Jakarta: Direktorat Jenderal Mineral dan Batubara. Available at: https://www.minerba.esdm.go.id/library/conte nt/file/28935-Lakin dan PK 2017/1c91c16e25684db9d5039a874a6748e 82018-04-11-10-12-42.pdf.

Dwivedi, A. and Jain, M. K. (2014) "Fly ash - waste management and overview: a review," Recent Research in Science and Technology, 6(1), pp. 30-35. Available at: http://updatepublishing.com/journal/index.ph $\mathrm{p} / \mathrm{rrst} / \mathrm{article} / \mathrm{view} / 1157$.

EEC (1991) Council Directive of 12 December 1991 on hazardous waste 91/689/EEC No. L $377 / 20$, Official Journal of the European Communities.

Fitriana, I., Anindhita, Sugiyono, A., Wahid, L. M. A. and Adiarso (eds.) (2017) Outlook energi Indonesia 2017: Inisiatif pengembangan teknologi energi bersih. Jakarta: Pusat Teknologi Sumber Daya Energi dan Industri Kimia.

Gitari, W. M., Petrik, L. F., Etchebers, O., Key, D. L. and Okujeni, C. (2008) "Utilization of fly ash for treatment of coal mines wastewater: Solubility controls on major inorganic contaminants," Fuel, 87(12), pp. 2450-2462. doi: 10.1016/j.fuel.2008.03.018.

Hadijah, N. R. and Damayanti, R. (2006) "Penelitian abu batubara sebagai pembenah tanah: pengaruh waktu inkubasi terhadap parameter kualitas tanah (derajat keasaman tanah $(\mathrm{pH}-\mathrm{H} 2 \mathrm{O}), \mathrm{Mn}, \mathrm{Fe}, \mathrm{P}$-total dan Ptersedia)," Jurnal Teknologi Mineral dan Batubara, 36(14), pp. 9-17. 
Hadijah, N. R., Khaerunnisa, H. and Untung, S. R. (2006) "Uji toksisitas akut LC50 bahan abu terbang dan abu dasar serta pengaruhnya terhadap reproduksi daphnia carinata king," Jurnal Teknologi Mineral dan Batubara, 37(14), pp. 29-36.

He, Y., Luo, Q. and Hu, H. (2012) "Situation analysis and countermeasures of China's fly ash pollution prevention and control," Procedia Environmental Sciences, 16, pp. 690-696.

doi: 10.1016/j.proenv.2012.10.095.

Hecker, G. and Bilski, J. (2014) "Environmental toxicology and coal fly ash chemical composition," Research Journal of Chemical and Environmental Science, 2(4), pp. 27-33. Available at: http://www.aelsindia.com/rjcesaugust2014/4. pdf.

Hikam, M. A. S. (ed.) (2014) Ketahanan energi Indonesia 2015 - 2025 tantangan dan harapan. Jakarta: CV. Rumah Buku.

Joshi, R. C. (2010) "Fly ash - production, variability and possible complete utilization," in Indian Geotechnical Conference - 2010, GEOtrendz. Mumbai: IGS Mumbai Chapter \& IIT Bombay, pp. 103-111. Available at: https://gndec.ac.in/ igs/ldh/conf/2010/article s/v012.pdf.

Khaerunnisa, H., Hadijah, N. R. and Damayanti, R. (2006) “Uji toksisitas akut LD50 bahan abu terbang dan abu dasar terhadap mencit galur Swis Webster," Jurnal Teknologi Mineral dan Batubara, 38(14), pp. 9-18.

Kurniawan, A. R., Adenan, D. D., Untung, S. R., Hadijah, N. R. and Alimano, M. (2010) Pemanfaatan abu batubara PLTU untuk penimbunan pada pra reklamasi tambang batubara. Bandung: Puslitbang tekMIRA.

Kurniawan, A. R., Surono, W. and Alimano, M. (2014) "Potensi pemanfaatan limbah pembakaran batubara PLTU sebagai media tanam dalam kegiatan revegetasi lahan bekas tambang batubara," Jurnal Teknologi Mineral dan Batubara, 10(3), pp. 142-154. Available at: http://jurnal.tekmira.esdm.go.id/index.php/mi nerba/article/view/730.

Lam, C. H. K., Ip, A. W. M., Barford, J. P. and McKay, G. (2010) "Use of incineration MSW ash: A review," Sustainability, 2(7), pp. 1943-1968. doi: 10.3390/su2071943.
Lokeshappa B and Dikshit, A. K. (2012) "Behaviour of metals in coal fly ash ponds," APCBEE Procedia, 1, pp. 34-39.

doi: 10.1016/j.apcbee.2012.03.007.

Mal'chik, A. G., Litovkin, S. V. and Rodionov, P. V. (2015) "Investigation of physicochemical properties of bottom-ash materials for use them as secondary raw materials," in IOP Conference Series: Materials Science and Engineering 91. Yurga, Russia: IOP Publishing, pp. 1-7. Available at: http://iopscience.iop.org/article/10.1088/1757 -899X/91/1/012030/meta.

Miod, M. C. (2008) The determination of heavy metals in coal ash. University Malaysia Sarawak. Available at: https://ir.unimas.my/7688/.

Office of Chief Economist (2016) Industri batubara, Industry Update, www.mandiri-institute.id. Available at: http://mandiriinstitute.id/files/industry-update-vol-3-2016industri-batubara/?upf $=$ vw\&id $=1780$ (Accessed: May 10, 2018).

Permana, A. D., Sugiyono, A., Suharyono, H. and Boedoyo, M. S. (eds.) (2010) Outlook energi Indonesia 2010: Teknologi untuk mendukung keandalan pasokan energi listrik. Jakarta: BPPT-Press.

PLN (1997) "Pengelolaan abu terbang dan abu dasar pembangkit listrik dengan bahan bakar batubara di indonesia." PT. PLN (Persero) PT. Kema Technology Indonesia.

PLN (2018) "Executive summary RUPTL PT. PLN (Persero) 2018," in Diseminasi RUPTL 2018 2017. PT PLN, p. 15. Available at: https://www.esdm.go.id/assets/media/content/ content-ringkasan-ruptl-2018-2027.pdf.

Presiden Republik Indonesia (2014) Peraturan Pemerintah No. 101 tentang pengelolaan limbah bahan berbahaya dan beracun. Indonesia. Available at:

https://www.ecostargrp.com/PP Nomor 101 Tahun 2014 tentang Pengelolaan Limbah B3.pdf.

Sherrard, R. M., Carriker, N. E. and Greeley, M. S. (2015) "How toxic is coal ash? A laboratory toxicity case study," Integrated Environmental Assessment and Management, 11(1), pp. 5-9. doi: 10.1002/ieam. 1587.

Sprint Consultant (2015) PLTU Paiton swasta tahap II Probolinggo, Jawa Timur. Jakarta. Available at: http://www.jawapower.co.id/?wpdmact = proc ess\&did $=$ MTAuaG90bGluaw $==$. 
Stiernström, S., Breitholtz, M., Lindé, M., Hemström, K., Enell, A. and Wik, O. (2012) "Classification of waste to enable utilization in an environmental safe way," in Arm, M., Vandecasteele, C., Heynen, J., Suer, P., and Lind, B. (eds.) WASCON 2012 Conference proceedings. Gothenburg, Sweden: ISCOWA and SGI, pp. 1-4.

Stiernström, S., Enell, A., Wik, O., Hemström, K. and Breitholtz, M. (2014) "Influence of leaching conditions for ecotoxicological classification of ash," Waste Management, 34(2), pp. 421-429.

doi: 10.1016/j.wasman.2013.10.041.

Stiernström, S., Hemström, K., Wik, O., Carlsson, G., Bengtsson, B.-E. and Breitholtz, M. (2011) "An ecotoxicological approach for hazard identification of energy ash," Waste Management, 31(2), pp. 342-352. doi: 10.1016/j.wasman.2010.05.019.

Stiernström, S., Wik, O. and Bendz, D. (2016) "Evaluation of frameworks for ecotoxicological hazard classification of waste," Waste Management, 58, pp. 14-24. doi: 10.1016/j.wasman.2016.08.030.

Suprapto, S. and Damayanti, R. (1988) Hasil pengujian sifat-sifat abu batubara Muara Tiga, Bukit Asam. Bandung.
Thahir, Z. A. (2017) Pemanfaatan fly ash dan bottom ash dari PLTU Suralaya Banten untuk pembuatan GEOPAV. Institut Teknologi Sepuluh Nopember. Available at: http://repository.its.ac.id/44709/.

Triwulan, Priadana, K. A., Ekaputri, J. J. and Bayuaji, R. (2017) "Physical and chemical character of fly ash of coal fired power plant in Java," in IOP Conference Series: Materials Science and Engineering. IOP Publishing, p. 012003. doi: 10.1088/1757-899X/267/1/012003.

Vuthaluru, H. B. and French, D. (2008) "Ash chemistry and mineralogy of an Indonesian coal during combustion," Fuel Processing Technology, 89(6), pp. 595-607. doi: 10.1016/j.fuproc.2007.12.002.

Wilke, B.-M., Riepert, F., Koch, C. and Kühne, T. (2008) "Ecotoxicological characterization of hazardous wastes," Ecotoxicology and Environmental Safety, 70(2), pp. 283-293. doi: 10.1016/j.ecoenv.2007.10.003.

Zhang, X. (2014) Management of coal combustion waste, Report CCC/231. IEA Clean Coal Centre. Available at: https://www.usea.org/publication/managemen t-coal-combustion-wastes-ccc231. 
